\title{
Systematic review of patient factors affecting adipose stem cell viability and function: implications for regenerative therapy
}

\author{
Jajini Varghese ${ }^{1 *+}$, Michelle Griffin ${ }^{1,2+}$, Afshin Mosahebi ${ }^{1,2}$ and Peter Butler ${ }^{1,2}$
}

\begin{abstract}
Background: The applications for fat grafting have increased recently, within both regenerative and reconstructive surgery. Although fat harvesting, processing and injection techniques have been extensively studied and standardised, this has not had a big impact on the variability of outcome following fat grafting. This suggests a possible larger role of patient characteristics on adipocyte and adipose-derived stem cell (ADSC) viability and function. This systematic review aims to collate current evidence on the effect of patient factors on adipocyte and ADSC behaviour.

Methods: A systematic literature review was performed using MEDLINE, Cochrane Library and EMBASE. It includes outcomes observed in in vitro analyses, in vivo animal studies and clinical studies. Data from basic science work have been included in the discussion to enhance our understanding of the mechanism behind ADSC behaviour.

Results: A total of 41 papers were included in this review. Accumulating evidence indicates decreased proliferation and differentiation potential of ADSCs with increasing age, body mass index, diabetes mellitus and exposure to radiotherapy and Tamoxifen, although this was not uniformly seen across all studies. Gender, donor site preference, HIV status and chemotherapy did not show a significant influence on fat retention. Circulating oestrogen levels have been shown to support both adipocyte function and graft viability. Evidence so far suggests no significant impact of total cholesterol, hypertension, renal disease, physical exercise and peripheral vascular disease on ADSC yield.

Conclusions: A more uniform comparison of all factors highlighted in this review, with the application of a combination of tests for each outcome measure, is essential to fully understand factors that affect adipocyte and ADSC viability, as well as functionality. As these patient factors interact, future studies looking at adipocyte viability need to take them into consideration for conclusions to be meaningful. This would provide crucial information for surgeons when deciding appropriate volumes of lipoaspirate to inject, improve patient selection, and counsel patient expectations with regards to outcomes and likelihood for repeat procedures. An improved understanding will also assist in identification of patient groups that would benefit from graft enrichment and cryopreservation techniques.
\end{abstract}

Keywords: Adipose-derived stem cells, Body mass index, Age, Stem cell therapy, Stem cell viability

\footnotetext{
* Correspondence: jajiniv@gmail.com

A. Mosahebi and P. E. Butler are joint senior authors.

${ }^{\dagger}$ Equal contributors

${ }^{1}$ Charles Wolfson Center for Reconstructive Surgery, Royal Free Hospital,

London, UK

Full list of author information is available at the end of the article
} 


\section{Background}

Autologous fat grafting has become a standard treatment for volume and contour defects in reconstructive surgery [1]. In 1983, Illouz and Sterodimas first described fat grafting, where the graft was obtained from a donor site through liposuction and re-injected immediately into the region of interest through syringes $[2,3]$. Stem cells isolated from bone marrow (BM-MSCs) are the most characterised and clinically studied stem cell source to date [4]. Passage number, expansion medium, culture conditions and stem cell source all influence mesenchymal stem cell (MSC) characteristics [5-7].

The painful isolation and low yield associated with BM-MSCs has prompted research into other stem cell sources. In 2001, Zuk et al. [8] isolated MSCs from adipose tissue with the same potential as BM-MSCs to differentiate not only into mesenchymal lineages, such as adipogenic, chondrogenic [9, 10], osteogenic [11, 12], myogenic [13] and cardiomyogenic [14] lines, but also into neurogenic [15], angiogenic $[16,17]$ and hepatic lineages [18]. Adipose-derived stem cells (ADSCs) also display immunosuppressive, anti-inflammatory and angiogenic properties through the release of soluble mediators in a paracrine fashion [19]. This together with the ease of isolation and abundant supply makes ADSCs attractive not only in the regenerative field but also as a tool to enhance the survival of fat grafts [20]. However, fat grafting has two main limitations, inconsistency with fat graft survival and poor reliability [21, 22].

Although fat harvesting, processing and injection techniques have been extensively studied and standardised, this has not had a big impact on the variability of outcome following fat grafting [23]. This suggests a possible larger role of patient characteristics on ADSC number, viability and functionality. This systematic review aims to collate evidence on the effect of patient factors on adipocyte and ADSC viability and functionality.

The isolation procedure for adipose tissue results in a stromal vascular fraction (SVF) layer that is composed of a host of cells, including stem cells, pericytes, monocytes, macrophages and capillary endothelial cells. Dominici et al. [24] provided the criteria to identify MSCs, which include plastic adherence, the expression of CD105, CD73 and CD90, a lack of expression of CD45, CD34, CD14 or CD11b, CD79alpha or CD19 and HLA-DR surface molecules and the ability to differentiate into osteoblasts, adipocytes and chondroblasts in vitro.

To avoid confusion through terminology, we refer to multipotent precursor cells from adipose tissue stroma as adipose-derived stem cells (ADSCs) [25].

\section{Methods}

An electronic search of the MEDLINE through PubMed and EMBASE databases was performed to identity all original clinical papers from 1959 to 2016 that described effects of patient factors, medication or systemic conditions on adipocyte viability, proliferation and differentiation potential (reviewed by two independent reviewers, J.V. and M.G.). For the same time period, all in vitro studies that assessed the effect of patient factors on adipocyte and ADSC function were identified. Keywords with Boolean operators used in the search included the following: "adipocyte" or "stem" or "ADSC" or "lipoaspirate" and "age" or "BMI" or "radiotherapy" or "diabetes" or "menopausal status" or "donor sites" or "HIV" or "cardiovascular disease" or "renal disease" or "gender". The full search strategy is provided in Additional file 1: Table S1 and Fig 1.

Articles were considered eligible if they met the following inclusion criteria: (1) clinical, in vitro and animal studies that evaluated the effect of patient factors on adipocyte or ADSC yield and or function; (2) the outcome measures included adipocyte or ADSC or SVF yield and/or function (differentiation and proliferation capacity).

Articles were excluded if they were: (1) papers describing effects of patient factors on stem cells of other origin, such as BM-MSCs; (2) studies not published in English, as the reviewers could not fully understand the manuscript; (3) editorials, publications on congress meetings, unpublished data or letters to the editor. Review articles were only used to contribute to the "Discussion" section and identify any other relevant articles.

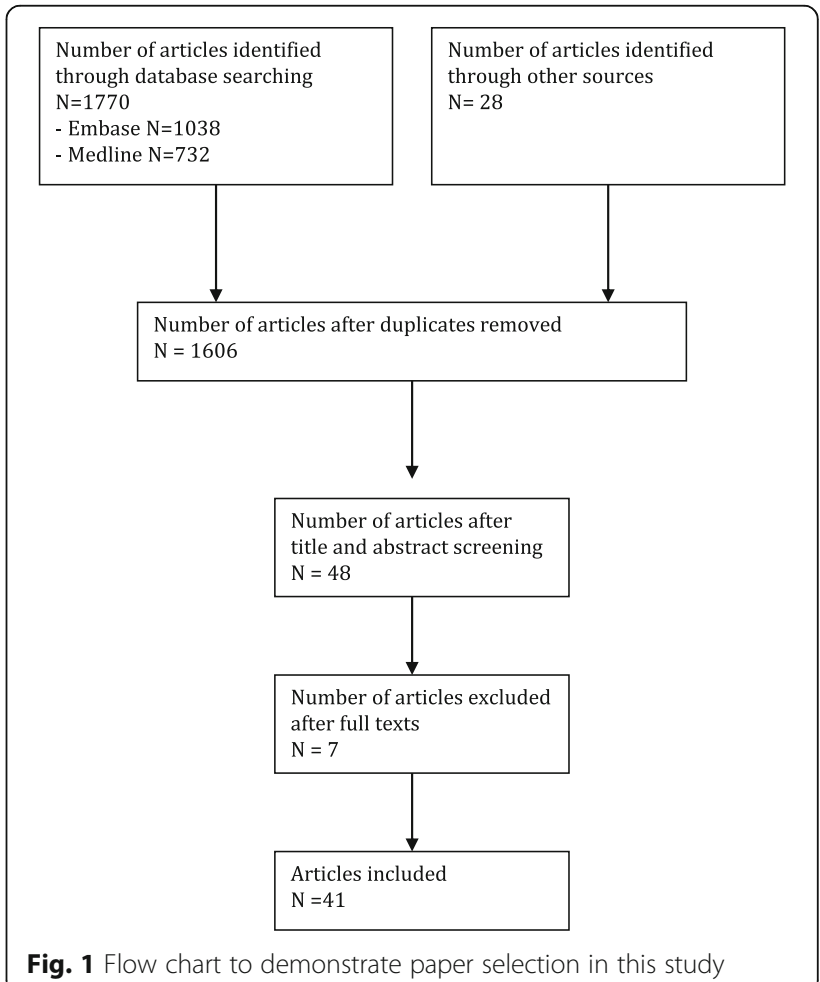


A variety of names were used in the included studies to describe the plastic-adherent cell population isolated from collagenase digests of adipose tissue. These included adipose-derived stem/stromal cells (ASCs), adipose-derived adult stem (ADAS) cells, adipose-derived stromal cells (ADSCs), adipose stromal cells (ASCs), adipose mesenchymal stem cells (AdMSCs), lipoblasts, pericytes, preadipocytes and processed lipoaspirate (PLA) cells. To avoid confusion we decided to adopt the term "adipose-derived stem cells" (ADSCs) to identify the isolated, plasticadherent, multipotent cell population as recommended by the International Fat Applied Technology Society.

Studies were assigned a Level of Evidence (LOE) adapted from the Oxford Centre for Evidence Based Medicine (http://www.cebm.net/index.aspx?o=1025) to establish whether valid and reliable evidence is present for effects of patient factors on adipocyte viability. These levels, ranging from LOE-1 to LOE-5, are based on methodology and study design. In brief, LOEs were assigned as follows: LOE $1=$ randomized control trial; LOE-2 = cohort study or cross-sectional study in consecutive participants; LOE-3 = case-control study; LOE-4= case series study; LOE-5 = animal studies, expert opinion or case report [26].

\section{Results}

The search for patient factors that affect SVF, adipocyte or ADSC yield and/or function led to the identification of the following factors described in the following sections: age, body mass index (BMI), gender, menopausal status, donor sites, HIV status and cancer treatments, including radiotherapy, chemotherapy and tamoxifen usage.

\section{Age}

Sixteen LOE-2 in vitro studies of human ADSCs and three LOE-5 animal studies reported on the effect of age on ADSC viability and function (Table 1). Twelve of these studies did not identify any effect on adipocyte yield [27-36]. However, more recent studies using gene expression measurements of senescence have shown a significant decrease in overall yield of nucleated cells with increasing age $[37,38]$ and, more potently, a significant decrease in the proliferative and differentiation capacities of ADSCs [35, 38-41]. Madonna et al. [42] compared omental ADSCs between 'young' ( $n=18,40-$ 54 years) and 'elderly' ( $n=22,66-92$ years) and reported significant decreases in ADSC yield and angiogenic capacity with increasing age. While Zhu et al. [43] did not find a significant effect on the adipogenic potential of ADSCs, advancing age significantly reduced osteogenic potential. This is supported by other studies that have reported similar age-dependant decreases in the osteogenic potential of ADSCs $[9,44]$. Such age-dependency of differentiation capacity has also been observed in rat ADSCs [45-47].

\section{Body mass index}

Fourteen LOE-2 studies investigated the effect of BMI on adipocyte viability. Eight studies demonstrated an effect of increasing BMI on adipocyte viability and function [28, 34, 48-52] (Table 2). In the largest study to date $(n=189)$, with 30 women within the 'obese' category $\left(\mathrm{BMI}>30 \mathrm{~kg} / \mathrm{m}^{2}\right)$, van Harmelan et al. [34] reported a significant reduction in the number of viable mature adipocytes per gram of adipose tissue and in the differentiation capacity of ADSCs with increasing BMI. This finding is supported by five other in vitro studies that also showed decreases in both differentiation and proliferation capacities of adipocytes with increasing BMI [28, 34, 48, 49, 51] (Table 2). Frazier et al. reported ADSCs from obese individuals were compromised in early adipogenic and osteogenic potential and correlated this with their potential to form colonies in vitro, which was inversely proportional to the individual's BMI.

In addition to the reduced capacity for differentiation and migration and angiogenic and proliferative abilities of ADSCs from obese humans [50, 52, 53], Perez et al. [51] also noted changes in telomerase activity and DNA telomere length, suggesting a decreased self-renewal capacity and early apoptosis. Isakson et al. [49] and Tang et al. [54] showed that this reduction in differentiation of enlarged ADSCs may be related to increased mitogen-activated protein 4 kinase 4 (MAP4K4) expression, which inhibits peroxisome proliferator-activated receptor (PPAR) $-\gamma$ activation and thereby adipogenesis.

It has been reported that after massive weight loss, subcutaneous adipose tissue returns to a non-inflammatory state with a significant decrease in cytokines [55]. Mitterberger compared ADSCs from 'formerly obese' patients who had undergone bariatric procedures to 'obese' and 'normal weight' individuals. They showed that bariatric surgery and diet-induced long-term calorie restriction substantially reprogrammed ADSCs, with reduced DNA damage, improved viability and extended replicative lifespan [56]. ADSCs isolated from ex-obese patients attained a mature adipocyte phenotype faster than those obtained from non-obese patients [57], suggesting an enrichment of cells in the ADSC population that are 'more prepared' for adipogenic differentiation.

Interestingly, six studies (LOE-2) reported no significant association with increasing BMI [27, 29, 31, 32, 35, 36]. Mojallal et al. reviewed in a prospective study 42 women with varying BMI. After dividing the patients into two groups (BMI $\leq 25$ or $>25 \mathrm{~kg} / \mathrm{m}^{2}$ ), they did not find a statistically significant correlation between BMI and proliferation [31]. Similarly, Faustini et al. [29] analysed data from 


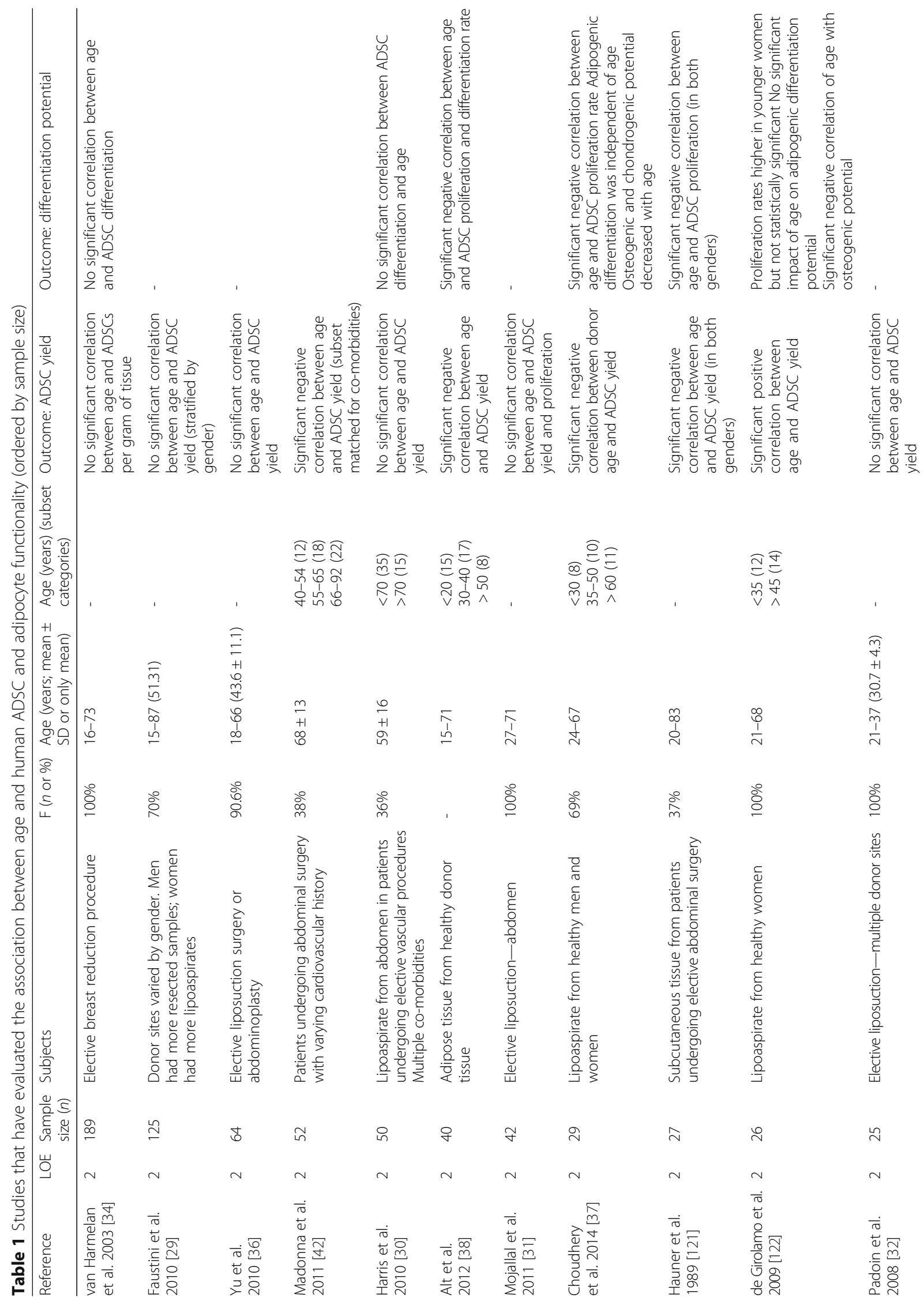




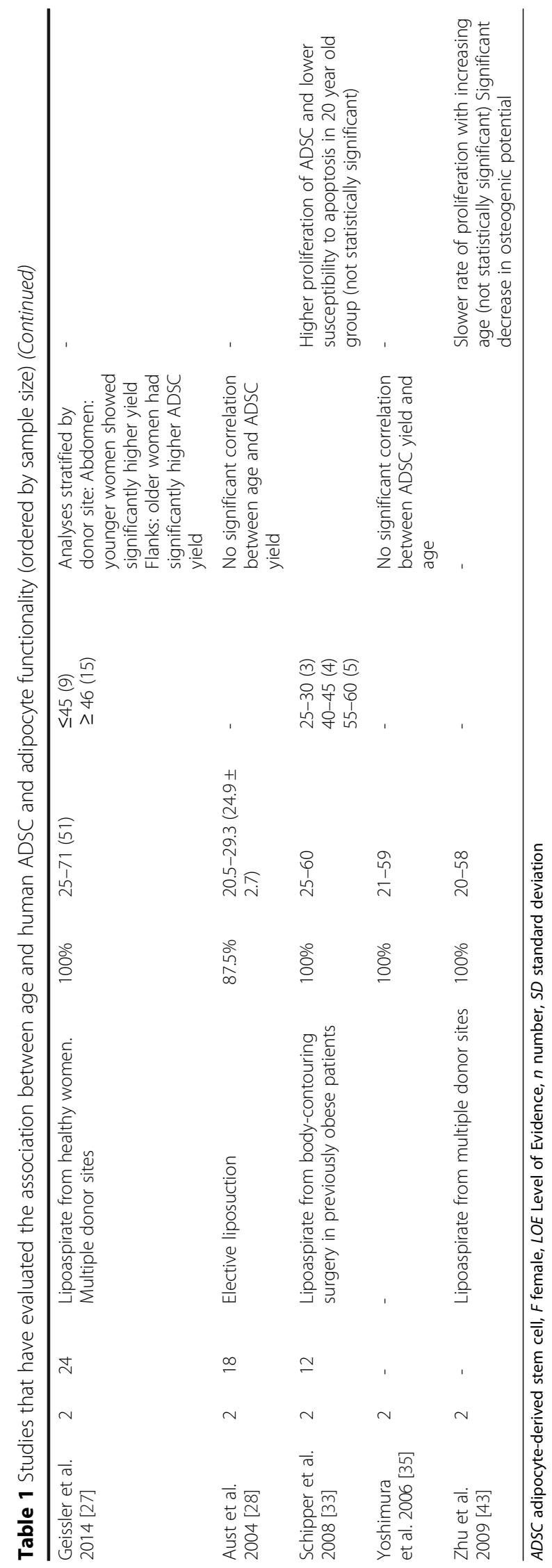




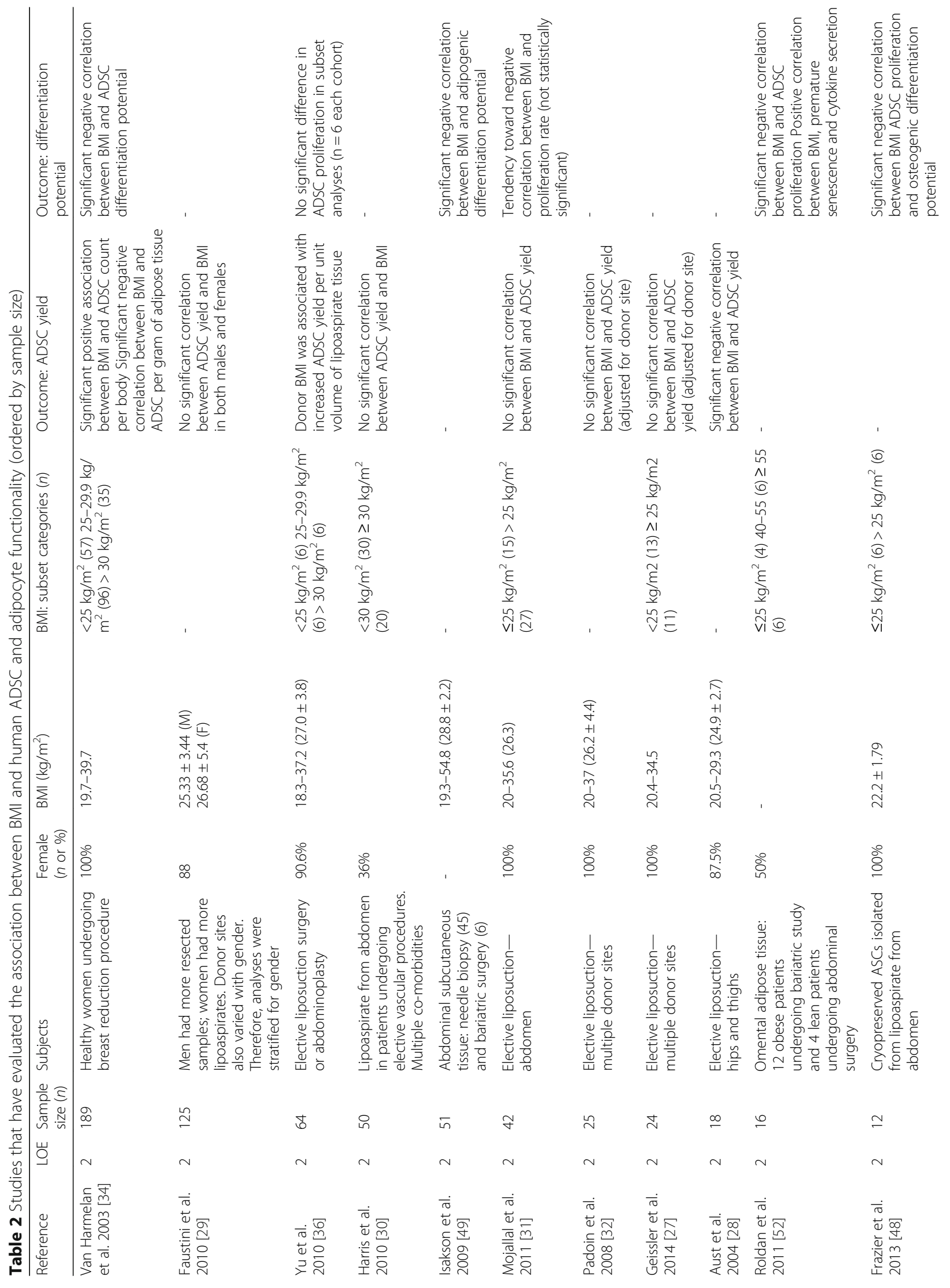




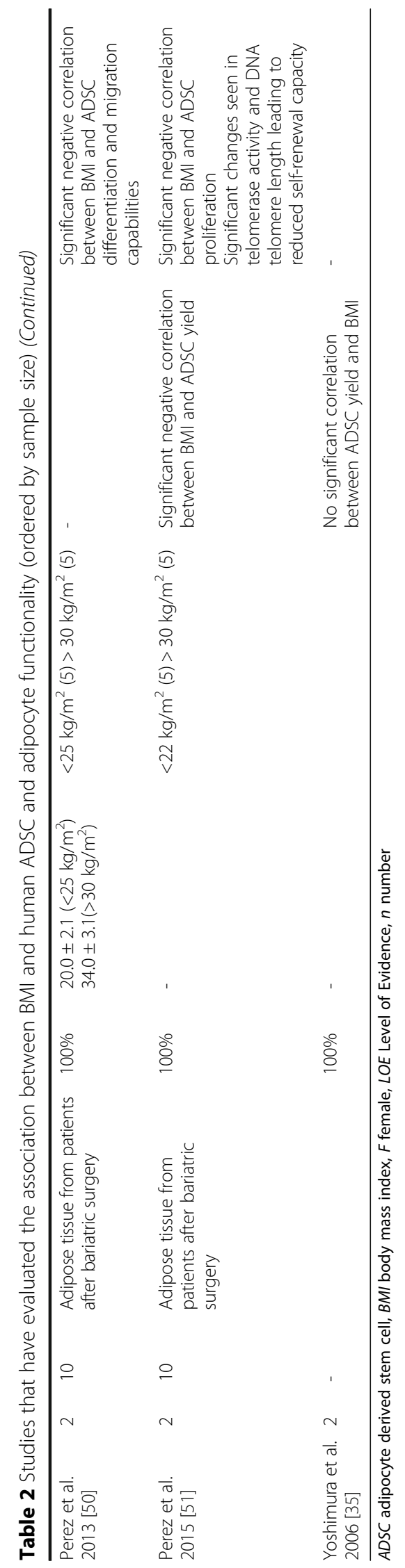


125 subjects stratified by gender and did not see an association among increasing donor BMI and ADSC yield or function (Table 2).

\section{Gender}

Ogawa et al. [58] showed in a LOE-5 study that PPAR[gamma]2 expression levels (marker of adipogenesis) were 2.89 times greater in ADSCs harvested from female mice compared to male mice, raising the possibility of a significant role of gender. In vitro LOE-2 studies of human ADSCs, however, have so far not shown any difference in ADSC yield and proliferation by gender [29, 30, 59]. Faustini et al. [29] studied 37 males and 88 females and reported that the best donor site among men in terms of yield was the abdomen. Aksu et al. [60] studied abdominoplasty tissue from three males and three females and reported that ADSCs from males showed more effective osteogenic differentiation compared to those from females.

\section{Menopausal status}

Three LOE-2 in vitro and one LOE-5 in vivo study in mice investigated the effect of menopausal status or oestrogen on adipocyte viability. Geissler et al. [27] reported increased adipocyte viability using lower abdominal fat from younger, presumably pre-menopausal women ( $<45$ years) compared to from older women, suggesting a modulatory role of circulating oestrogen levels. However, information regarding hormonal status or supplements was not gathered.

To further examine the effect of circulating oestrogens on fat graft outcomes, the same group later harvested adipose tissue from inguinal pads of mice that underwent either 'sham' or 'ovariectomy' operations, which was then injected into another set of mice [61]. The fat grafts from mice that had the 'sham' procedure, and therefore circulating oestrogen, were softer and showed higher capillary density and higher expression of proangiogenic factors.

Interestingly, transfer of lipoaspirate into 'sham' or 'ovariectomy' recipients did not alter the weight or vascular density 45 days after transplantation, suggesting a smaller role of circulating oestrogen post-fat transfer [61]. Addition of 17ß-oestradiol to ADSCs has been shown to significantly improve adipogenic differentiation with enhanced survival of fat transfer by reducing apoptosis in nude mice $[62,63]$.

\section{Donor site}

The search for the ideal donor site for fat harvest is ongoing. So far ten LOE-2 in vitro studies using human ADSCs and one LOE-5 animal study have investigated donor site as a potential influence on adipocyte behaviour. Of the ten studies of human ADSCs, only three found any difference in adipocyte behaviour between different sites (Table 3). Padoin et al. [32] $(n=25)$ showed that fat from the lower abdomen and medial thighs has higher ADSC yield compared to the upper abdomen, trochanteric region, knees and flanks. Jurgens et al. [64] $(n=22)$ also reported significantly higher ADSC yield from abdominal aspirate with no significant differences in differentiation capacity. Geissler et al. [27] $(n=24)$ reported greater adipocyte viability in lipoaspirates from lower abdomen compared to from flanks and inner thighs, evident only in a subset of younger women ( $<45$ years). There is some evidence to suggest higher ADSC yields from abdominal tissue compared to back and knee among men [29]. However, this difference was not seen among women. This is in agreement with previous studies suggesting that the choice of donor site has little effect on fat graft outcomes [32, 65-68]. Within the abdomen, fat superficial to the Scarpas layer displays increased multipotency and stemness features compared to a deep abdominal depot $[33,69]$.

\section{Radiotherapy, chemotherapy and tamoxifen}

A LOE-5 study by Poglio et al. [70] investigated mice after whole body radiation and reported that adipose tissue can be deeply damaged by radiotherapy, significantly reducing both the number and proliferation capacity of ADSCs.

Administration of immunosuppressive medications such as anti-lymphocyte treatment and alemtuzumab (lytic monoclonal antibodies) and tacrolimus for lymphocyte depletion following composite tissue transplantation have been shown to decrease both the viability and proliferative capacity of ADSCs in a dose-dependant manner [71].

In vitro exposure of human ADSCs to increasing doses of tamoxifen, a selective oestrogen receptor modulator used in breast cancer treatment, resulted in apoptosis, inhibition of proliferation and differentiation in a doseand time-dependent manner [72]. Interestingly, Liang et al. [73] reported no difference in differentiation potential of ADSCs in vitro when exposed to three commonly used chemotherapeutic agents: cisplatin, comptothecin and vincristine.

\section{Diabetes mellitus}

A LOE-2 study compared gene expression profiles of ADSCs in diabetic patients to those in age- and BMImatched controls. They reported a significant decrease in ADSC differentiation capacity and up-regulation of genes involved in inflammation and apoptosis in the diabetic patients [74]. Harris et al. [30] reported a trend of lower yields of ADSCs in diabetics $(n=18)$ which was not statistically significant.

Three LOE-5 animal studies investigated the effect of fat grafting in a diabetic setting. Choi et al. [75] demonstrated a higher resorption in rats with diabetes over 


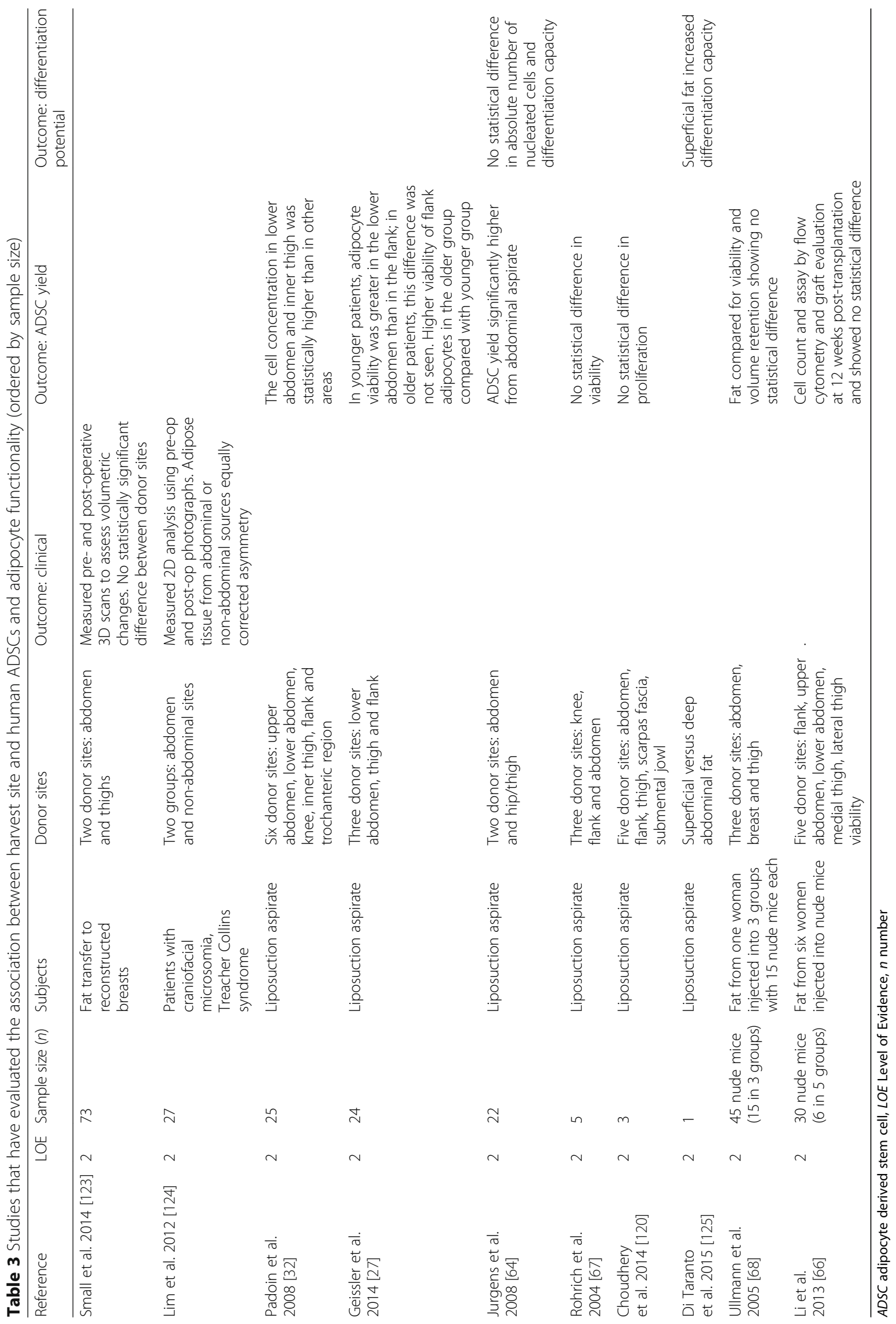


90 days. This was supported by Jung et al. [76] with reports of significantly lower weights, volumes and vascularity in the diabetic group compared to the control group. Ferrer-Lorente et al. [77] used a different approach and analysed gene expression in subcutaneous adipose tissue from Zucker diabetic fatty rats and their non-diabetic controls. The subcutaneous adipose tissue of diabetic rats displayed widespread downregulation of markers of stemness and differentiation and angiogenic potential.

\section{Discussion}

This review aims to identify patient characteristics that may influence adipocyte and ADSC viability and behaviour in order to have a greater understanding of how to improve fat graft retention rates. Peer first postulated the 'Cell Survival' theory, suggesting the number of viable cells within the graft correlated with the long-term survival of grafts $[78,79]$. The restorative and reconstructive qualities of fat grafting have been attributed to ADSCs within the graft [80]. Moreover, addition of ADSCs to transplanted fat was reported to support the formation of new vasculature and promote graft retention [20, 41, 81].

A total of 41 papers were included in this review. Most were in vitro studies on human tissue (LOE-2) and used similar in vitro techniques to analyse the effects of different patient factors on adipocyte and ADSC count as well as function. However, it is difficult to make conclusive recommendations as it is not clear whether the in vitro findings translate to clinically significant differences. Methods of adipocyte isolation and processing protocols also varied among the studies and this is known to affect yield $[82,83]$. The included studies mostly had modest sample sizes and consisted of healthy patients undergoing elective plastic surgery procedures; therefore, the homogeneity in the sample may have reduced the power. Most studies did not report on other ADSC functions such as immunodulatory or angiogenic properties.

With an aging population, fat transfer procedures, particularly for regenerative properties, are becoming more relevant. Age-related changes in fat tissue inflammatory profiles resemble those in obesity, in which senescent stem cells and endothelial cells accumulate along with an increase in circulating pro-inflammatory cytokines, including TNF $\alpha$ and IL-6 [84, 85]. This increased cytokine release by ADSCs activates adjacent cells into a pro-inflammatory state, impeding adipogenesis and promoting fat cell lipolysis [86].

Advanced age is known to have detrimental effects on blood and BM-MSCs [87-89]. In contrast, ADSC yield seemed to be stable across age groups in 12 of 16 LOE-2 studies included in this review (Table 1). The subjects in most of these studies were having elective cosmetic procedures and therefore the homogeneity of subjects, with very few subjects being elderly ( $>70$ years), may have reduced the power to detect an effect. However, it is reassuring to know that ADSC yield appears relatively stable across age groups. Similarly, BMI was also found to have little effect on ADSC yield in 12 LOE-2 studies. Although the absolute yield of precursor cells per gram of adipose tissue was reduced in some studies, this can be explained by the initial increase in adipocyte size seen with weight gain $[90,91]$. These findings demonstrate the reproducibility of adipose tissue as a consistent and abundant source of ADSCs across a spectrum of ages and BMI values.

Unsurprisingly there is evidence to support reduced proliferative and differentiation capacities with increasing age $[30,34,37,38]$, which is likely related to the decreased susceptibility of precursor cells to respond to extracellular signals. Similarly, increasing BMI, particularly within the obese category (BMI $>30 \mathrm{~kg} / \mathrm{m} 2)$, was observed to negatively impact ADSC functional capacities, with implications for their use in cellular therapies and reconstructive surgery (Table 2). Although larger in size, these adipocytes in obese individuals have been shown to be deficient in perilipin phosphoproteins, which are found on the cell surface and act as gatekeepers preventing lipases from hydrolyzing triacylglycerol [92]. This deficiency may contribute to fragile cell membranes, thereby potentially increasing the basal rate of lipolysis [93]. Another important consequence of adipocyte enlargement is the development of local inflammation with infiltration of monocytes/macrophages that act as scavengers of the remaining debris and lipids [94] and higher expression of pro-inflammatory proteins, including TNF- $\alpha$, IL- 6 and factor VII, affecting adipocyte survival and functional capacities in recipient sites [51, 95]. So far no clinical studies have investigated if these cellular changes translate into clinical differences. Graft enrichment through supplementation of ADSCs may be relevant for this cohort, along with weight reduction interventions.

No clinical studies have yet set out to address associations between gender, menopausal status and hormone replacement therapies and ADSC yield. Circulating oestrogen is a major regulator of adipose tissue, exerting its effects primarily through two oestrogen receptors (ERs), ER- $\alpha$ and ER- $\beta$. Studies have shown variable distribution of these receptors among fat depots, affecting responses to oestrogen signalling [96, 97]. Depletion of oestrogen levels, for instance in post-menopausal women or in ovariectomised mice, have been associated with an increase in lipolytic activity, adipocyte diameter, oxidative stress and inflammation [98].

In a questionnaire study among 508 surgeons practising in the US, the most preferred site for fat harvest was the abdomen (89\%), followed by thighs (34\%) [99]. So far, clinical studies have not yet been able to identify an ideal donor site. Therefore, when used as fillers, site 
choice may be made on ease, safety of access, fat abundance and patient preference. Nevertheless, application of grafts harvested from a single depot has been advised, especially for treatment of mirror zones (e.g. nasolabial folds, cheeks ) as there is in vitro evidence that adipocytes from different anatomical depots exhibit different morphology and functional capacity [33, 100]. For example, the distributions of adrenergic receptor subtypes on adipocytes vary between depots, with abdominal subcutaneous depots showing higher concentrations of adrenergic receptors than gluteo-femoral adipose tissue [101]. Therefore, abdominal depots in general are characterized by a higher lipid turnover and undergo increased lipolysis in response to adrenergic stress stimuli.

In comparison, lower-body fat stores have reduced lipid turnover, retain the capacity to recruit additional adipocytes as a result of weight gain, demonstrate fewer signs of inflammatory insult and tend to be more resistant to TNFo-induced apoptosis than abdominal ADSCs in in vitro studies $[100,102,103]$. New data suggest that these profound functional differences between upperbody and lower-body tissues are controlled by sitespecific expression of developmental genes that direct both the degree of adipocyte proliferation and aspects of differentiation $[65,100,104]$. It is accepted, therefore, that adipocytes from different subcutaneous depots (abdominal versus gluteal) are developmentally distinct and are cell autonomous, which means that even after transplantation during fat transfer procedures, they can be expected to have distinct phenotypes $[105,106]$. How they interact with the microenvironment in recipient sites has not yet been studied in detail. It is possible gene regulation determines depot-specific properties during development and sex steroids play a modulatory role [27].

Additional data are required to determine whether these findings translate into long-term retention. Most studies have rarely considered interactions between gender, BMI, menopausal status and other potential confounders and were of modest sample sizes (Table 3). Nevertheless, current clinical data suggest there is no significant difference in the volume or weight of grafted fat from different donor sites.

Radiotherapy is increasingly being used to treat numerous human malignancies [107]. Altered molecular signalling and formation of reactive oxygen species cause singlestranded DNA breaks that do not repair completely and activate premature senescence or accelerated terminal differentiation [108]. Despite improved resilience of ADSCs through their superior DNA damage repair mechanisms and reduced metabolic demands that protect them from hypoxia and subsequent apoptosis $[109,110]$, studies have demonstrated that radiotherapy adversely affects ADSCs, necessitating the introduction of non-irradiated progenitor cells from distant donor sites [70, 107].
Fat transfer in radiotherapy patients is further complicated by the fact that irradiated recipient sites have unfavourable microenvironments for graft survival because of hypoxia and chronic inflammatory states. Furthermore, stem cells within the injured area recruit myofibroblastlike cells, which in turn contribute to fibrosis [111]. The immunoregulatory capacity of transferred ADSCs to modulate inflammation and thereby reduce fibrosis and its normalising role in tissue regeneration have been well documented [112, 113].

Use of tamoxifen is routinely discontinued before and after major surgery because of the increased risk of venous thrombo-embolism with no documented effect on increased cancer risk [114]. Given that tamoxifen has a dose- and time-dependant detrimental effect on ADSCs, discontinuing its use to support fat engraftment and survival may be beneficial.

The link between chronic diseases like diabetes and impaired BM-MSC properties is well established [115-117]. Evidence collated from LOE-5 animal studies also supports the detrimental effects of diabetes on ADSC function, potentially limiting its potency in regenerative and reconstructive surgery [30,74-77]. The effect of other common diseases and medications should also be further investigated. Evidence so far suggests no significant impact of total cholesterol, hypertension, renal disease, physical exercise and peripheral vascular disease on ADSC yield [30, 42].

Currently, surgeons aim to improve fat graft resorption by optimising the fat harvest and injection techniques and preparation of the recipient bed [118]. An improved understanding of patient factors that affect fat viability and function would assist in the identification of patient groups that could potentially benefit from graft enrichment techniques. Surgeons may consider transferring larger volumes of processed fat and adopt techniques to boost levels of ADSCs in grafts using techniques such as cell assisted lipotransfer [31, 37, 38], where part of the lipoaspirate is used to extract ADSCs, which are then used to supplement the cellular suspension before transplant.

Alternative strategies such as banking younger adipose tissue when biological activity is at its greatest potential or before chemoradiotherapy has become an option with cryopreservation techniques $[119,120]$. Transfer of smaller fat particles and serial transfers of smaller volumes at closer intervals may also support adipocyte survival within adverse microenvironments by reducing demand [112]. The search for the ideal fat particle size for transfer is ongoing [79].

\section{Conclusions}

Overall the literature is sparse, with varied methodologies used to compare the effects of different factors on 
adipocyte and ADSC functionality. A more uniform comparison of all factors highlighted in this review, with the application of a combination of tests for each outcome measure, is essential to fully understand factors that affect adipocyte and ADSC viability as well as function. This would be crucial information for surgeons when deciding appropriate volumes of lipoaspirate to inject, improve patient selection, and counsel patient expectations with regards to outcomes and likelihood for repeat procedures.

\section{Additional files}

Additional file 1: Table S1. Search strategy summary. (DOC 32 kb)

\section{Abbreviations}

ADSC: Adipose-derived stem cell; BM: Bone marrow; BMI: Body mass index; LOE: Level of Evidence; MSC: Mesenchymal stem cell; SVF: Stromal vascular fraction

\section{Acknowledgments}

None.

\section{Funding}

We would like to thank the funding from Medical Research Council and Action Medical Research, which provided MG a clinical fellowship to conduct this work, GN 2339.

\section{Availability of data and materials}

Data set available from JV.

\section{Authors' contributions}

JV and MG collected and analysed the literature and wrote the manuscript. PE and AM edited and reviewed the manuscript. All authors read and approved the final manuscript.

\section{Authors' information}

$\mathrm{JV}$ is a Plastic Surgery registrar based at the Royal Free Hospital. MG is an academic clinical fellow in plastic surgery based at University College London (UCL). AM is a Consultant Plastic Surgeon at Royal Free Hospital and PE is a Professor of Plastic Surgery at the University College London (UCL) and a consultant at the Royal Free Hospital.

\section{Competing interests}

The authors declare that they have no competing interests.

\section{Consent for publication}

Not required.

Ethics approval and consent to participate

Not required.

\section{Author details}

${ }^{1}$ Charles Wolfson Center for Reconstructive Surgery, Royal Free Hospital, London, UK. ${ }^{2}$ UCL Centre for Nanotechnology and Regenerative Medicine, Division of Surgery \& Interventional Science, University College London, London, UK.

Published online: 28 February 2017

\section{References}

1. Rohrich RJ. The American Society of Plastic Surgeons' procedural statistics: what they really mean. Plast Reconstr Surg. 2003;112:1389-92.

2. Illouz YG. Body contouring by lipolysis: a 5-year experience with over 3000 cases. Plast Reconstr Surg. 1983;72:591-7.
3. Illouz YG, Sterodimas A. Autologous fat transplantation to the breast: a personal technique with 25 years of experience. Aesthetic Plast Surg. 2009; 33:706-15.

4. Griffin M, Kalaskar DM, Butler PE, Seifalian AM. The use of adipose stem cells in cranial facial surgery. Stem Cell Rev. 2014;10:671-85.

5. Chase LG, Yang S, Zachar V, Yang Z, Lakshmipathy U, Bradford J, et al. Development and characterization of a clinically compliant xeno-free culture medium in good manufacturing practice for human multipotent mesenchymal stem cells. Stem Cells Transl Med. 2012;1:750-8.

6. Chen G, Yue A, Ruan Z, Yin Y, Wang R, Ren Y, et al. Comparison of biological characteristics of mesenchymal stem cells derived from maternalorigin placenta and Wharton's jelly. Stem Cell Res Ther. 2015;6:228.

7. Hass R, Kasper C, Bohm S, Jacobs R. Different populations and sources of human mesenchymal stem cells (MSC): A comparison of adult and neonatal tissue-derived MSC. Cell Commun Signal. 2011;9:12.

8. Zuk PA, Zhu M, Mizuno H, Huang J, Futrell JW, Katz AJ, et al. Multilineage cells from human adipose tissue: implications for cell-based therapies. Tissue Eng. 2001;7:211-28.

9. Erickson GR, Gimble JM, Franklin DM, Rice HE, Awad H, Guilak F. Chondrogenic potential of adipose tissue-derived stromal cells in vitro and in vivo. Biochem Biophys Res Commun. 2002;290:763-9.

10. Huang Jl, Zuk PA, Jones NF, Zhu M, Lorenz HP, Hedrick MH, et al. Chondrogenic potential of multipotential cells from human adipose tissue. Plast Reconstr Surg. 2004;113:585-94.

11. Halvorsen YC, Wilkison WO, Gimble JM. Adipose-derived stromal cells-their utility and potential in bone formation. Int J Obes Relat Metab Disord. 2000; 24 Suppl 4:S41-4

12. Peterson B, Zhang J, Iglesias R, Kabo M, Hedrick M, Benhaim P, et al. Healing of critically sized femoral defects, using genetically modified mesenchymal stem cells from human adipose tissue. Tissue Eng. 2005;11:120-9.

13. Mizuno H, Zuk PA, Zhu M, Lorenz HP, Benhaim P, Hedrick MH. Myogenic differentiation by human processed lipoaspirate cells. Plast Reconstr Surg. 2002;109:199-209.

14. Strem BM, Zhu M, Alfonso Z, Daniels EJ, Schreiber R, Beygui R, et al. Expression of cardiomyocytic markers on adipose tissue-derived cells in a murine model of acute myocardial injury. Cytotherapy. 2005;7:282-91.

15. Ashjian PH, Elbarbary AS, Edmonds B, DeUgarte D, Zhu M, Zuk PA, et al. In vitro differentiation of human processed lipoaspirate cells into early neural progenitors. Plast Reconstr Surg. 2003;111:1922-31.

16. Cao Y, Sun Z, Liao L, Meng Y, Han Q, Zhao RC. Human adipose tissuederived stem cells differentiate into endothelial cells in vitro and improve postnatal neovascularization in vivo. Biochem Biophys Res Commun. 2005; 332:370-9.

17. Rehman J, Traktuev D, Li J, Merfeld-Clauss S, Temm-Grove CJ, Bovenkerk JE, et al. Secretion of angiogenic and antiapoptotic factors by human adipose stromal cells. Circulation. 2004;109:1292-8.

18. Seo MJ, Suh SY, Bae YC, Jung JS. Differentiation of human adipose stromal cells into hepatic lineage in vitro and in vivo. Biochem Biophys Res Commun. 2005:328:258-64.

19. Prockop DJ, Brenner M, Fibbe WE, Horwitz E, Le BK, Phinney DG, et al. Defining the risks of mesenchymal stromal cell therapy. Cytotherapy. 2010; 12:576-8.

20. Trojahn Kolle SF, Oliveri RS, Glovinski PV, Elberg JJ, Fischer-Nielsen A, Drzewiecki KT. Importance of mesenchymal stem cells in autologous fat grafting: a systematic review of existing studies. J Plast Surg Hand Surg. 2012;46:59-68.

21. Delay E, Garson S, Tousson G, Sinna R. Fat injection to the breast: technique, results, and indications based on 880 procedures over 10 years. Aesthet Surg J. 2009;29:360-76.

22. Nishimura T, Hashimoto H, Nakanishi I, Furukawa M. Microvascular angiogenesis and apoptosis in the survival of free fat grafts. Laryngoscope. 2000;110:1333-8.

23. Strong AL, Cederna PS, Rubin JP, Coleman SR, Levi B. The current state of fat grafting: a review of harvesting, processing, and injection techniques. Plast Reconstr Surg. 2015;136:897-912.

24. Dominici M, Le BK, Mueller I, Slaper-Cortenbach I, Marini F, Krause D, et al. Minimal criteria for defining multipotent mesenchymal stromal cells. The International Society for Cellular Therapy position statement. Cytotherapy. 2006;8:315-7.

25. Gimble JM, Katz AJ, Bunnell BA. Adipose-derived stem cells for regenerative medicine. Circ Res. 2007;100:1249-60.

26. Griffin M, Bayat A. Electrical stimulation in bone healing: critical analysis by evaluating levels of evidence. Eplasty. 2011;11:e34. 
27. Geissler PJ, Davis K, Roostaeian J, Unger J, Huang J, Rohrich RJ. Improving fat transfer viability: the role of aging, body mass index, and harvest site. Plast Reconstr Surg. 2014;134:227-32.

28. Aust L, Devlin B, Foster SJ. Yield of human adipose-derived adult stem cells from liposuction aspirates. Cytotherapy. 2004;6(1):7-14.

29. Faustini M, Bucco M, Chlapanidas T, Lucconi G, Marazzi M, Tosca MC, et al. Nonexpanded mesenchymal stem cells for regenerative medicine: yield in stromal vascular fraction from adipose tissues. Tissue Eng Part C Methods. 2010;16:1515-21.

30. Harris $\amalg$, Zhang P, Abdollahi H, Tarola NA, DiMatteo C, Mcllhenny SE, et al. Availability of adipose-derived stem cells in patients undergoing vascular surgical procedures. J Surg Res. 2010;163:e105-12.

31. Mojallal A, Lequeux C, Shipkov C, Duclos A, Braye F, Rohrich R, et al. Influence of age and body mass index on the yield and proliferation capacity of adipose-derived stem cells. Aesthetic Plast Surg. 2011;35:1097-105.

32. Padoin AV, Braga-Silva J, Martins P, Rezende K, Rezende AR, Grechi B, et al. Sources of processed lipoaspirate cells: influence of donor site on cell concentration. Plast Reconstr Surg. 2008;122:614-8.

33. Schipper BM, Marra KG, Zhang W, Donnenberg AD, Rubin JP. Regional anatomic and age effects on cell function of human adipose-derived stem cells. Ann Plast Surg. 2008;60:538-44.

34. van Harmelen V, Skurk T, Rohrig K, Lee YM, Halbleib M, Aprath-Husmann I, et al. Effect of BMI and age on adipose tissue cellularity and differentiation capacity in women. Int J Obes Relat Metab Disord. 2003;27:889-95.

35. Yoshimura K, Shigeura T, Matsumoto D, Sato T, Takaki Y, Aiba-Kojima E, et al. Characterization of freshly isolated and cultured cells derived from the fatty and fluid portions of liposuction aspirates. J Cell Physiol. 2006;208:64-76.

36. Yu G, Wu X, Dietrich MA, Polk P, Scott LK, Ptitsyn AA, et al. Yield and characterization of subcutaneous human adipose-derived stem cells by flow cytometric and adipogenic mRNA analyzes. Cytotherapy. 2010;12:538-46.

37. Choudhery MS, Badowski M, Muise A, Pierce J, Harris DT. Donor age negatively impacts adipose tissue-derived mesenchymal stem cell expansion and differentiation. J Transl Med. 2014;12:8.

38. Alt EU, Senst C, Murthy SN, Slakey DP, Dupin CL, Chaffin AE, et al. Aging alters tissue resident mesenchymal stem cell properties. Stem Cell Res. 2012;8:215-25.

39. Efimenko A, Starostina E, Kalinina N, Stolzing A. Angiogenic properties of aged adipose derived mesenchymal stem cells after hypoxic conditioning. J Transl Med. 2011;9:10

40. Goodman JW, Lopa S, Arrigoni E, Sartori MF, Baruffaldi Preis FW, Brini AT. Human adipose-derived stem cells isolated from young and elderly women: their differentiation potential and scaffold interaction during in vitro osteoblastic differentiation. Cytotherapy. 2009;11:793-803.

41. Moseley TA, Zhu M, Hedrick MH. Adipose-derived stem and progenitor cells as fillers in plastic and reconstructive surgery. Plast Reconstr Surg. 2006:118:121S-8S.

42. Madonna R, Renna FV, Cellini C, Cotellese R, Picardi N, Francomano F, et al. Age-dependent impairment of number and angiogenic potential of adipose tissue-derived progenitor cells. Eur J Clin Invest. 2011;41:126-33.

43. Zhu M, Kohan E, Bradley J, Hedrick M, Benhaim P, Zuk P. The effect of age on osteogenic, adipogenic and proliferative potential of female adiposederived stem cells. J Tissue Eng Regen Med. 2009;3:290-301.

44. de Giolamo L, Lopa S, Arrigoni E. Human adipose-deived stem cells isolated from young and elderly women:their differentiation potential and scaffold interaction during in vitro osteoblastic differentiation. Cytotherapy. 2009; 11(6):793-803

45. Bjorntorp P, Karlsson M, Pettersson P, Sypniewska G. Differentiation and function of rat adipocyte precursor cells in primary culture. J Lipid Res. 1980:21:714-23.

46. Deslex S, Negrel R, Ailhaud G. Development of a chemically defined serumfree medium for differentiation of rat adipose precursor cells. Exp Cell Res. 1987;168:15-30.

47. Djian $\mathrm{P}$, Roncari AK, Hollenberg $\mathrm{CH}$. Influence of anatomic site and age on the replication and differentiation of rat adipocyte precursors in culture. J Clin Invest. 1983;72:1200-8

48. Frazier TP, Gimble JM, Devay JW, Tucker HA, Chiu ES, Rowan BG. Body mass index affects proliferation and osteogenic differentiation of human subcutaneous adipose tissue-derived stem cells. BMC Cell Biol. 2013;14:34.

49. Isakson P, Hammarstedt A, Gustafson B. Impaired preadipocyte differentiation in human abdominal obesity. Diabetes. 2009;58(7):1550-7.

50. Perez LM, Bernal A, San MN, Galvez BG. Obese-derived ASCs show impaired migration and angiogenesis properties. Arch Physiol Biochem. 2013;119:195-201.
51. Perez LM, Bernal A, de Lucas B, San MN, Mastrangelo A, Garcia A, et al. Altered metabolic and stemness capacity of adipose tissue-derived stem cells from obese mouse and human. PLoS One. 2015;10:e0123397.

52. Roldan M, Macias-Gonzalez M, Garcia R, Tinahones FJ, Martin M. Obesity short-circuits stemness gene network in human adipose multipotent stem cells. FASEB J. 2011;25:4111-26.

53. Perez LM, Bernal A, San MN, Lorenzo M, Fernandez-Veledo S, Galvez BG. Metabolic rescue of obese adipose-derived stem cells by Lin28/Let7 pathway. Diabetes. 2013;62:2368-79.

54. Tang X, Guilherme A, Chakladar A, Powelka AM, Konda S, Virbasius JV, et al. An RNA interference-based screen identifies MAP4K4/NIK as a negative regulator of PPARgamma, adipogenesis, and insulin-responsive hexose transport. Proc Natl Acad Sci U S A. 2006;103:2087-92.

55. Moschen AR, Molnar C, Geiger S, Graziadei I, Ebenbichler CF, Weiss H, et al. Antiinflammatory effects of excessive weight loss: potent suppression of adipose interleukin 6 and tumour necrosis factor alpha expression. Gut. 2010;59:1259-64.

56. Mitterberger MC, Mattesich M, Zwerschke W. Bariatric surgery and dietinduced long-term caloric restriction protect subcutaneous adipose-derived stromal/progenitor cells and prolong their life span in formerly obese humans. Exp Gerontol. 2014;56:106-13.

57. Baptista LS, da Silva KR, da Pedrosa CS, Claudio-da-Silva C, Carneiro JR, Aniceto $\mathrm{M}$, et al. Adipose tissue of control and ex-obese patients exhibit differences in blood vessel content and resident mesenchymal stem cell population. Obes Surg. 2009;19:1304-12.

58. Ogawa R, Mizuno H, Hyakusoku H, Watanabe A, Migita M, Shimada T. Chondrogenic and osteogenic differentiation of adipose-derived stem cells isolated from GFP transgenic mice. J Nippon Med Sch. 2004;71:240-1.

59. Van Harmelen V, Rohrig K, Hauner H. Comparison of proliferation and differentiation capacity of human adipocyte precursor cells from the omental and subcutaneous adipose tissue depot of obese subjects. Metabolism. 2004;53:632-7.

60. Aksu AE, Rubin JP, Dudas JR, Marra KG. Role of gender and anatomical region on induction of osteogenic differentiation of human adipose-derived stem cells. Ann Plast Surg. 2008;60:306-22.

61. Bills JD, Derderian C, Barker J, Lowe A, Lavery LA, Davis KE. The role of estrogen in the modulation of autologous fat graft outcomes. Plast Reconstr Surg. 2015;135:103e-13e.

62. Luo S, Hao L, Li X, Yu D, Diao Z, Ren L, et al. Adipose tissue-derived stem cells treated with estradiol enhance survival of autologous fat transplants. Tohoku J Exp Med. 2013;231:101-10.

63. Zhou J, Lu P, Ren H, Zheng Z, Ji J, Liu H, et al. 17beta-estradiol protects human eyelid-derived adipose stem cells against cytotoxicity and increases transplanted cell survival in spinal cord injury. J Cell Mol Med. 2014;18:326-43.

64. Jurgens WJ, Oedayrajsingh-Varma MJ, Helder MN, Zandiehdoulabi B, Schouten TE, Kuik DJ, et al. Effect of tissue-harvesting site on yield of stem cells derived from adipose tissue: implications for cell-based therapies. Cell Tissue Res. 2008;332:415-26.

65. Karastergiou K, Fried SK, Xie H, Lee MJ, Divoux A, Rosencrantz MA, et al. Distinct developmental signatures of human abdominal and gluteal subcutaneous adipose tissue depots. J Clin Endocrinol Metab. 2013;98:362-71.

66. Li K, Gao J, Zhang Z, Li J, Cha P, Liao Y, et al. Selection of donor site for fat grafting and cell isolation. Aesthetic Plast Surg. 2013;37:153-8.

67. Rohrich RJ, Sorokin ES, Brown SA. In search of improved fat transfer viability: a quantitative analysis of the role of centrifugation and harvest site. Plast Reconstr Surg. 2004;113:391-5.

68. Ullmann Y, Shoshani O, Fodor A, Ramon Y, Carmi N, Eldor L, et al. Searching for the favorable donor site for fat injection: in vivo study using the nude mice model. Dermatol Surg. 2005;31:1304-7.

69. Di TG, Cicione C, Visconti G, Isgro MA, Barba M, Di SE, et al. Qualitative and quantitative differences of adipose-derived stromal cells from superficial and deep subcutaneous lipoaspirates: a matter of fat. Cytotherapy. 2015;17:1076-89.

70. Poglio S, Galvani S, Bour S, Andre M, Prunet-Marcassus B, Penicaud L, et al. Adipose tissue sensitivity to radiation exposure. Am J Pathol. 2009;174:44-53.

71. Tsuji W, Schnider JT, McLaughlin MM, Schweizer R, Zhang W, Solari MG, et al. Effects of immunosuppressive drugs on viability and susceptibility of adiposeand bone marrow-derived mesenchymal stem cells. Front Immunol. 2015;6:131.

72. Pike S, Zhang P, Wei Z, Wu N, Klinger A, Chang S, et al. In vitro effects of tamoxifen on adipose-derived stem cells. Wound Repair Regen. 2015;23:728-36.

73. Liang W, Xia H, Li J, Zhao RC. Human adipose tissue derived mesenchymal stem cells are resistant to several chemotherapeutic agents. Cytotechnology. $2011 ; 63: 523-30$. 
74. van Tienen FH, van der Kallen CJ, Lindsey PJ, Wanders RJ, van Greevenbroek MM, Smeets HJ. Preadipocytes of type 2 diabetes subjects display an intrinsic gene expression profile of decreased differentiation capacity. Int J Obes (Lond). 2011;35:1154-64.

75. Choi YD, Shin HS, Mok JO. Impaired survival of autologous fat grafts by diabetes mellitus in an animal model: a pilot study. Aesthet Surg J. 2014; 24(7):1246-52

76. Jung JA, Kim YW, Cheon YW. Effects of the diabetic condition on grafted fat survival:an experimental study using streptozotocin-induced diabetic rats. Arch Plast Surg. 2014;41(3):241-7.

77. Ferrer-Lorente R, Bejar MT, Tous M, Vilahur G, Badimon L. Systems biology approach to identify alterations in the stem cell reservoir of subcutaneous adipose tissue in a rat model of diabetes: effects on differentiation potential and function. Diabetologia. 2014;57:246-56.

78. Peer LA. The neglected free fat graft, its behavior and clinical use. Am J Surg. 1956;92:40-7

79. Gause TM, Kling RE, Sivak WN, Marra KG, Rubin JP, Kokai LE. Particle size in fat graft retention: A review on the impact of harvesting technique in lipofilling surgical outcomes. Adipocyte. 2014;3:273-9.

80. Yoshimura K, Eto H, Kato H, Doi K, Aoi N. In vivo manipulation of stem cells for adipose tissue repair/reconstruction. Regen Med. 2011;6:33-41.

81. Yoshimura K, Sato K, Aoi N, Kurita M, Hirohi T, Harii K. Cell-assisted lipotransfer for cosmetic breast augmentation: supportive use of adiposederived stem/stromal cells. Aesthetic Plast Surg. 2008;32:48-55.

82. Sethe S, Scutt A, Stolzing A. Aging of mesenchymal stem cells. Ageing Res Rev. 2006;5:91-116.

83. Oedayrajsingh-Varma MJ, van Ham SM, Knippenberg M, Helder MN, KleinNulend J, Schouten TE, et al. Adipose tissue-derived mesenchymal stem cell yield and growth characteristics are affected by the tissue-harvesting procedure. Cytotherapy. 2006;8:166-77.

84. Morin CL, Pagliassotti MJ, Windmiller D, Eckel RH. Adipose tissue-derived tumor necrosis factor-alpha activity is elevated in older rats. J Gerontol A Biol Sci Med Sci. 1997;52:B190-5.

85. Starr ME, Evers BM, Saito H. Age-associated increase in cytokine production during systemic inflammation: adipose tissue as a major source of IL-6. J Gerontol A Biol Sci Med Sci. 2009:64:723-30.

86. Zhang L, Ebenezer PJ, Dasuri K, Fernandez-Kim SO, Francis J, Mariappan N, et al. Aging is associated with hypoxia and oxidative stress in adipose tissue: implications for adipose function. Am J Physiol Endocrinol Metab. 2011;301:E599-607.

87. D'Ippolito G, Schiller PC, Ricordi C, Roos BA, Howard GA. Age-related osteogenic potential of mesenchymal stromal stem cells from human vertebral bone marrow. J Bone Miner Res. 1999:14:1115-22.

88. Justesen J, Stenderup K, Eriksen EF, Kassem M. Maintenance of osteoblastic and adipocytic differentiation potential with age and osteoporosis in human marrow stromal cell cultures. Calcif Tissue Int. 2002;71:36-44.

89. Nishida S, Endo N, Yamagiwa H, Tanizawa T, Takahashi HE. Number of osteoprogenitor cells in human bone marrow markedly decreases after skeletal maturation. J Bone Miner Metab. 1999;17:171-7.

90. Faust IM, Johnson PR, Stern JS, Hirsch J. Diet-induced adipocyte number increase in adult rats: a new model of obesity. Am J Physiol. 1978;235:E279-86

91. Hirsch J, Batchelor B. Adipose tissue cellularity in human obesity. Clin Endocrinol Metab. 1976;5:299-311.

92. Wang Y, Sullivan S, Trujillo M, Lee MJ, Schneider SH, Brolin RE, et al. Perilipin expression in human adipose tissues: effects of severe obesity, gender, and depot. Obes Res. 2003;11:930-6.

93. Greenberg AS, Obin MS. Obesity and the role of adipose tissue in inflammation and metabolism. Am J Clin Nutr. 2006:83:461S-5S.

94. Weisberg SP, McCann D, Desai M, Rosenbaum M, Leibel RL, Ferrante Jr AW. Obesity is associated with macrophage accumulation in adipose tissue. J Clin Invest. 2003;112:1796-808.

95. Isakson P, Hammarstedt A, Gustafson B, Smith U. Impaired preadipocyte differentiation in human abdominal obesity: role of Wnt, tumor necrosis factor-alpha, and inflammation. Diabetes. 2009;58:1550-7.

96. Gorres BK, Bomhoff GL, Gupte AA, Geiger PC. Altered estrogen receptor expression in skeletal muscle and adipose tissue of female rats fed a highfat diet. J Appl Physiol (1985). 2011;110:1046-53.

97. Rodriguez-Cuenca S, Monjo M, Proenza AM, Roca P. Depot differences in steroid receptor expression in adipose tissue: possible role of the local steroid milieu. Am J Physiol Endocrinol Metab. 2005;288:E200-7.
98. Brown LM, Gent L, Davis K, Clegg DJ. Metabolic impact of sex hormones on obesity. Brain Res. 2010;1350:77-85.

99. Kaufman MR, Bradley JP, Dickinson B, Heller JB, Wasson K, O'Hara C, et al. Autologous fat transfer national consensus survey: trends in techniques for harvest, preparation, and application, and perception of short- and longterm results. Plast Reconstr Surg. 2007;119:323-31.

100. Fried SK, Lee MJ, Karastergiou K. Shaping fat distribution: new insights into the molecular determinants of depot- and sex-dependent adipose biology. Obesity (Silver Spring). 2015;23:1345-52.

101. Leibel RL, Edens NK, Fried SK. Physiologic basis for the control of body fat distribution in humans. Annu Rev Nutr. 1989:9:417-43.

102. Hudson DA, Lambert EV, Bloch CE. Site selection for fat autotransplantation: some observations. Aesthetic Plast Surg. 1990;14:195-7.

103. Tchoukalova YD, Votruba SB, Tchkonia T, Giorgadze N, Kirkland JL, Jensen MD. Regional differences in cellular mechanisms of adipose tissue gain with overfeeding. Proc Natl Acad Sci U S A. 2010;107:18226-31.

104. Pinnick KE, Nicholson G, Manolopoulos KN, McQuaid SE, Valet P, Frayn KN, et al. Distinct developmental profile of lower-body adipose tissue defines resistance against obesity-associated metabolic complications. Diabetes. 2014;63:3785-97.

105. Foster MT, Softic S, Caldwell J, Kohli R, de Kloet AD, Seeley RJ. Subcutaneous adipose tissue transplantation in diet-induced obese mice attenuates metabolic dysregulation while removal exacerbates it. Physiol Rep. 2013;1:1-12.

106. Tran TT, Yamamoto Y, Gesta S, Kahn CR. Beneficial effects of subcutaneous fat transplantation on metabolism. Cell Metab. 2008;7:410-20.

107. Shukla L, Morrison WA, Shayan R. Adipose-derived stem cells in radiotherapy injury: a new frontier. Front Surg. 2015;2:1.

108. Stewart FA, Akleyev AV, Hauer-Jensen M, Hendry JH, Kleiman NJ, Macvittie TJ, et al. ICRP publication 118: ICRP statement on tissue reactions and early and late effects of radiation in normal tissues and organs-threshold doses for tissue reactions in a radiation protection context. Ann ICRP. 2012;41:1-322.

109. Chen MF, Lin CT, Chen WC, Yang CT, Chen CC, Liao SK, et al. The sensitivity of human mesenchymal stem cells to ionizing radiation. Int J Radiat Oncol Biol Phys. 2006;66:244-53.

110. Eto H, Kato H, Suga H, Aoi N, Doi K, Kuno S, et al. The fate of adipocytes after nonvascularized fat grafting: evidence of early death and replacement of adipocytes. Plast Reconstr Surg. 2012;129:1081-92.

111. Marigo I, Dazzi F. The immunomodulatory properties of mesenchymal stem cells. Semin Immunopathol. 2011;33:593-602.

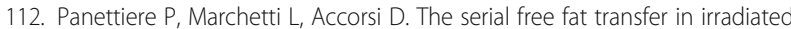
prosthetic breast reconstructions. Aesthetic Plast Surg. 2009;33:695-700.

113. Rigotti G, Marchi A, Galie M, Baroni G, Benati D, Krampera M, et al. Clinical treatment of radiotherapy tissue damage by lipoaspirate transplant: a healing process mediated by adipose-derived adult stem cells. Plast Reconstr Surg. 2007:119:1409-22.

114. Cushman M, Costantino JP, Bovill EG, Wickerham DL, Buckley L, Roberts JD, et al. Effect of tamoxifen on venous thrombosis risk factors in women without cancer: the Breast Cancer Prevention Trial. Br J Haematol. 2003;120:109-16.

115. Capla JM, Grogan RH, Callaghan MJ, Galiano RD, Tepper OM, Ceradini DJ, et al. Diabetes impairs endothelial progenitor cell-mediated blood vessel formation in response to hypoxia. Plast Reconstr Surg. 2007;119:59-70.

116. Choi JH, Kim KL, Huh W, Kim B, Byun J, Suh W, et al. Decreased number and impaired angiogenic function of endothelial progenitor cells in patients with chronic renal failure. Arterioscler Thromb Vasc Biol. 2004;24:1246-52.

117. Loomans $C J$, de Koning EJ, Staal FJ, Rookmaaker MB, Verseyden C, de Boer HC, et al. Endothelial progenitor cell dysfunction: a novel concept in the pathogenesis of vascular complications of type 1 diabetes. Diabetes. 2004;53:195-9.

118. Glovinski PV, Herly M, Muller FC, Elberg JJ, Kolle ST, Fischer-Nielsen A, et al. Avoiding a systematic error in assessing fat graft sunvival in the breast with repeated magnetic resonance imaging. Plast Reconstr Surg Glob Open. 2016;4:e1023.

119. Pu LL, Coleman SR, Cui X, Ferguson Jr RE, Vasconez HC. Cryopreservation of autologous fat grafts harvested with the Coleman technique. Ann Plast Surg. 2010;64:333-7.

120. Choudhery MS, Badowski M, Muise A, Pierce J, Harris DT. Cryopreservation of whole adipose tissue for future use in regenerative medicine. J Surg Res. 2014;187:24-35.

121. Hauner H, Entenmann G, Wabitsch M, Gaillard D, Ailhaud G, Negrel R, Pfeiffer EF. Promoting effect of glucocorticoids on the differentiation of human adipocyte precursor cells cultured in a chemically defined medium. J Clin Invest. 1989;84(5):1663-1670.

122. de Girolamo L, Lopa S, Arrigoni E, Sartori MF, Baruffaldi Preis FW, Brini AT. Human adipose-derived stem cells isolated from young and elderly women: 
their differentiation potential and scaffold interaction during in vitro osteoblastic differentiation. Cytotherapy. 2009;11(6):793-803.

123. Small K, Choi M, Petruolo O, Lee C, Karp N. Is there an ideal donor site of fat for secondary breast reconstruction? Aesthet Surg J. 2014:34(4):545-50.

124. Lim AA, Fan K, Allam KA, Wan D, Tabit C, Liao E, Kawamoto HK, Bradley JP. Autologous fat transplantation in the craniofacial patient: the UCLA experience. J Craniofac Surg. 2012;23(4):1061-6.

125. Di Taranto G, Cicione C, Visconti G, Isgrò MA, Barba M, Di Stasio E, Stigliano E, Bernardini C, Michetti F, Salgarello M, Lattanzi W. Qualitative and quantitative differences of adipose-derived stromal cells from superficial and deep subcutaneous lipoaspirates: a matter of fat. Cytotherapy. 2015;17(8): 1076-89. 